\title{
Zé-do-Burro e o destino trágico do antimalandro
}

\author{
Carlos Augusto Leite
}

\begin{abstract}
Resumo: este artigo busca compreender Zé-do-Burro, protagonista de $O$ pagador de promessas, peça de Dias Gomes, como representativa da categoria que se optou por denominar "antimalandro". Com base no célebre artigo de Antônio Cândido, "A dialética da malandragem", analisaram-se os eixos da "ordem" e da "desordem", representados na peça, a fim de argumentar pelo predomínio do signo da intransigência na construção desta personagem.
\end{abstract}

Palavras-chave: antimalandro, personagem, teatro, cultura.

\begin{abstract}
Zé-do-Burro, main character of $O$ pagador de promessas, a Dias Gomes' play, as representative of the category that it has been decided to call "antimalandro". Based on the famous Antônio Cândido's article, "A dialética da malandragem", the axis of "order" and "disorder" represented in the play have been analysed to argue the prevalence of the intransigence sign in this character building.
\end{abstract}

Keywords: antimalandro, character, drama, culture.

\section{Introdução}

Este ensaio tem por objetivo analisar a peça $O$ pagador de promessas, de Dias Gomes, sob a luz do artigo "Dialética da malandragem", de Antônio Cândido (2000, p.17-46), principalmente no que tange às ações tomadas pelo protagonista Zé-do-Burro ao longo de sua trajetória dramática. Embora o artigo mobilizado não verse especificamente sobre o drama em questão, irá se propor aqui que a absoluta intransigência demonstrada por Zé-do-Burro no decorrer da peça - intransigência esta que culmina em seu fim trágico -, pode ser interpretada, por meio do aparato crítico proposto por Cândido, como característica distintiva de uma espécie de antimalandro, como tal, incapaz de transitar com êxito entre os pólos da "ordem" e da "desordem" (Ibidem, p.32 e ss.), ao custo de modestas ou significativas concessões éticas.

Desta forma, além da relação a que o crítico se refere em seu texto, verificar-se-ia uma segunda dialética, cujos pólos seriam representados por Leonardo, principal personagem de Memórias de um sargento de milícias, e Zé-do-Burro, protagonista de $O$ pagador de promessas. Enquanto o primeiro parte de um plano mediano, oscilando entre a "ordem" (superior) e a "desordem" (inferior), em direção ao pólo da "ordem", ao final do livro

\footnotetext{
* Graduado em Lingüística pela Universidade Estadual de Campinas. Especializando-se em Literatura Brasileira pela UFRGS.
} 
(Ibidem), o protagonista de Dias Gomes permanece estático neste mesmo plano equatorial ${ }^{1}$, ancorado em sua promessa, sem realizar quaisquer concessões, quer ao plano da "ordem" (na peça: Igreja, Lei e Família), quer ao plano da "desordem" (igualmente: pequeno comércio, capoeiristas e meretrício), até o momento trágico de sua morte, no fim do drama.

É possível definir, portanto, por meio da relação dos protagonistas com as demais personagens, tanto do romance quanto do drama, uma tópica literária caracteristicamente nacional para o entendimento das personagens. Não constituída por heróis, anti-heróis e vilões, categorias dependentes e subalternas ao enredo, nem mesmo tripartida em caxias, peregrinos e malandros, como propõe DAMATTA (1997) ao identificar tipos recorrentes da sociedade brasileira e suas dramatizações sociais representativas; mas caracterizada, de um lado, por aqueles aptos ao dialogismo ético, os malandros e, do outro, por aqueles que pautam sua conduta pela intransigência e pela recusa, os antimalandros.

Após identificar as características de Zé-do-Burro que o aproximam dessa segunda categoria, este ensaio, como conclusão, verifica no artigo crítico de Antônio Cândido as características que comporiam o malandro para, a partir delas, traçar um paralelismo que auxilie na composição de sua contraparte, o antimalandro. Se houve êxito em seu objetivo, este ensaio acaba por propor uma segunda figura que componha, junto ao malandro de Cândido, um aparato crítico confiável e profícuo para a o estudo de personagens como Zé-doBurro, construídos sob o signo da recusa, avessos ao dialogismo ético.

\section{As recusas de Zé-do-Burro}

Para concretizar a proposta deste ensaio, é preciso, primeiramente, verificar como ocorrem as ações realizadas por Zé-do-Burro e se há algum traço que as convirja para um ponto comum. Se há algo que se pode associar indubitavelmente a todas as ações do protagonista de $O$ pagador de promessas, é sua intransigência. Derivada do verbo latino transiggere, que significa "chegar a acordo", "condescender" (CUNHA, 1982), a palavra traduz bem a caracterização de Zé-do-Burro quanto à sua inflexibilidade, austeridade de caráter e, principalmente, no caso da peça, seu rigor na imobilidade de certas crenças ou princípios pessoais. Para se compor a figura do antimalandro, ou aquele que se recusa ao diálogo entre a "ordem" e a "desordem", por conseguinte, é necessário identificar os diversos

\footnotetext{
${ }^{1}$ O plano mediano reservado ao peregrino é inspirado nos argumentos de DAMATTA (1990), p.263 e ss.
} 
momentos da peça em que se torne flagrante uma postura intransigente por parte do peregrino.

Antes cabe uma ressalva. As recusas por parte do protagonista, no decorrer da obra, não são todas obviamente de mesma magnitude. Algumas são decisivas para o desfecho da trama, enquanto outras somente reforçam a caracterização da personagem. O importante para este ensaio, contudo, é pautar-se na afirmação de que, “ao longo do drama, não há nenhuma ação que vá de encontro à intransigência apresentada pelo peregrino". Ou seja, embora haja ações de outras naturezas, em que a personagem não recuse algo nem explicitamente se negue ao diálogo, não há qualquer condescendência por parte de Zé-do-Burro a qualquer proposta dirigida a ele, quer dos representantes da "ordem", quer dos representantes da "desordem". Essa renúncia inabalável é decisiva para que a personagem surja como privilegiada para a conceituação da figura proposta do antimalandro.

\subsection{Avesso à ordem}

Dito isso, dentre as ações que definem a trajetória do protagonista, pode-se destacar, primeiramente, sua recusa ao lidar com os representantes da dimensão da "ordem". O antropólogo Roberto DaMatta identifica três grandes eixos, na hierarquizante sociedade brasileira, que se concebem como atemporais: Igreja, Estado e Família (1997, p.25-29). Visto que esta atemporalidade pode ser aproximada a um ordenado caráter civilizatório que prefere a manutenção à ruptura, optou-se, neste ensaio, por identificar as três grandes instâncias apontadas por DaMatta como componentes possíveis e singularizados do eixo da "ordem". Como essas três esferas estão representadas na peça, pôde-se aqui analisar detidamente a relação entre Zé-do-Burro e cada uma delas para se verificar a hipótese de que o peregrino nega firmemente dialogar com quaisquer dos componentes deste eixo.

A Igreja, por exemplo, é representada na peça por quatro personagens: o sacristão, Padre Olavo, o Monsenhor e o Arcebispo. Salvo o primeiro, que inicialmente mantém uma relação amena com o peregrino, também porque hierarquicamente estaria mais próximo a este, e o último, que só figura na peça referencialmente, como uma instância muito superior do poder eclesiástico, Zé-do-Burro mostra-se absoluta e constantemente arredio em relação aos representantes da Igreja. Exemplos desta esquiva ocorrem quando o protagonista se recusa a deixar a praça, mesmo ao ser coagido por Padre Olavo a isso - "Padre, eu não andei sete léguas para voltar daqui" (GOMES, 2002, p.52) -, ou, ainda, quando não aceita a possibilidade de ter sua promessa quitada ou transmutada pelo Monsenhor, ao que o Padre vaticina: "resta agora você escolher entre a tolerância da Igreja e a sua própria intransigência" 
(Ibidem, p.102). Embora a Igreja não provoque diretamente a morte de Zé-do-Burro, a insubmissão do protagonista, ou sua recusa ao âmbito de influência e proteção da Igreja, faz com que ele permaneça na praça com a cruz de madeira e isso acaba por resultar em certa vulnerabilidade fundamental para o seu fim trágico. Também cabe à Igreja a primeira marca de insubmissão dada a Zé-do-Burro, por meio da alcunha de herege, no episódio em que o padre o acusa de querer se comparar a Jesus Cristo e de ter feito a promessa em um terreiro "fetichista" (Ibidem, p.49-50). Estas alcunhas, mesmo que pontuais, parecem funcionar como um reconhecimento oficial da condição transgressora do indivíduo e significam certamente um abandono por parte da esfera da "ordem" ou da "desordem" 2 que a emite.

Não se verifica uma relação menos conflituosa entre Zé-do-Burro e a esfera do Estado, militar à época, representado nas figuras do Guarda, do "Secreta", do Delegado e do Comissário. Não obstante o amigável primeiro contato com o Guarda, que Dias Gomes descreve como um homem esquivo à sua responsabilidade (Ibidem, p.59), uma espécie de malandro da "ordem", as tensões entre Zé-do-Burro e o Estado aumentam gradativamente a partir do instante em que o protagonista rejeita a sugestão do Guarda em arrumar uma saída para o impasse ("mas o senhor bem que podia ter arranjado uma promessinha menos complicada"). Daí em diante, com a Igreja e Zé-do-Burro já de laços desfeitos, o Guarda deixa de se interpor e torna o peregrino vulnerável à futura ação do "Secreta" e do Delegado, que culminarão em sua morte. Cabe destacar, como exemplo privilegiado da intransigência do pagador de promessas, as respostas que ele dá ao "Secreta", quando este lhe dirige um pequeno interrogatório para averiguar sua periculosidade. Pleno de sarcasmo, irredutibilidade e fúria, Zé-do-Burro se apresenta totalmente avesso ao diálogo que lhe poderia salvar a vida e ainda concede ao interrogador a prova (ao mencionar a palavra "bomba") de que este precisava para atribuir-lhe a alcunha de subversor, outra marca condenatória, e decidir prendê-lo. Esse diálogo consiste em um exemplo notável para o ensaio, pois, mais do que recusar uma ajuda, renunciar completamente ao diálogo parece se configurar como o auge da intransigência de um antimalandro e, o que na peça pode ser verificado nos eventos em que Zé-do-Burro assume uma postura de maior recrudescimento (posteriormente, com Dedé Cospe-Rima e com a Imprensa).

A título de comentário, somente para evidenciar uma constatação que se torna óbvia após a análise das duas primeiras esferas do eixo da "ordem", é possível notar no drama certa natureza simétrica. Tanto a Igreja quanto o Estado trazem quatro personagens em suas fileiras.

\footnotetext{
${ }^{2}$ Como exemplo, sem se deter muito no tema, a esfera da desordem parece ser capaz de proferir uma marca análoga em acusações como "alcagüete", "vira-casaca", "traíra", dentre outras.
} 
Numa ordem hierarquizada, o de menor posição é quem lida da melhor maneira com Zé-doBurro, os dois intermediários são quem lhe fazem valer a ordem e condenam-no, enquanto o de maior posição não aparece efetivamente na peça, mas é referido pelos demais como uma instância máxima da esfera que representam. Longe de se buscar aqui uma análise mais detalhada a respeito, a gradação simétrica parece representar bem o realismo social ${ }^{3}$ encenado em muitas das peças de Dias Gomes, onde pouco importa verdadeiramente grande parte das personagens, mas sim a posição social que preenchem em suas hierarquias e no quadro pintado pelo dramaturgo. Além disso, pode-se também apontar para alguma semelhança com o que Cândido afirma ocorrer em Memórias de um Sargento de Milícias, onde a obra "é circunscrita a um tipo de gente livre e modesta" (2000, p.27), sem a presença das camadas mais extremas do meio retratado.

Encerrado o comentário, e de volta ao escopo escolhido para este artigo, das três esferas inspiradas na obra de DaMatta, resta apenas detalhar a relação de Zé-do-Burro com a Família, para que a análise do eixo da "ordem" esteja completa. À exceção de Nicolau, o burro que nomeia a personagem e mantém com ele uma relação próxima a de parentesco - "um burro com alma de gente" (GOMES, 2002, p.51) -, a família do peregrino se resume à sua esposa, Rosa, que o acompanha em toda a saga, salvo no momento derradeiro, em que o abandona. Não podendo ser diferente, também em diversos momentos se mostra a recusa de Zé-doBurro em aceitar qualquer auxílio ou admoestação de sua mulher. Do simples ato de dispensar "almofadinhas" para atenuar o peso da cruz de madeira (Ibidem, p.11), até negar-se duas vezes a ir embora a pedido de Rosa (Ibidem, p.64 e 118), negação, aliás, que dá o contorno decisivo à tragédia do peregrino, Zé-do-Burro também media sua relação com a esposa pela renúncia. Em toda a peça, Rosa é a personagem que mais busca dialogar com Zé-do-Burro e convencê-lo a desistir de sua promessa. Inutilmente, no entanto, pois o protagonista mais uma vez mantém-se apartado das concessões que poderiam eximi-lo de seu fim trágico, e prefere, em última instância, manter o monólogo com sua promessa a qualquer diálogo que lhe amenize o peso da situação peculiar em que se encontra.

Ao negar por completo, como se espera ter evidenciado, qualquer diálogo com a Igreja, a Lei e a Família, o peregrino demonstra sua intransigência absoluta em relação a todo o eixo da "ordem", afastando, por conseqüência, qualquer auxílio que lhe poderia advir de uma

\footnotetext{
${ }^{3}$ SZONDI (2002) identifica esta característica como típicas da crise do drama moderno e a ascensão do que chama "forma épica" no teatro. Em especial, há um quadro comparativo às páginas 134-135. Especificamente sobre Dias Gomes, pode-se averiguar seu engajamento político em RIDENTI (2000), p.88-89 e 171-172.
} 
dimensão superior à sua e facilitar, com algumas exigências (propinas morais, sociais etc.), o cumprimento de sua promessa.

\subsection{Avesso à desordem}

Após se verificar a relação, absolutamente pautada pelo signo da renúncia, do pagador de promessas com eixo da "ordem", é necessário complementar a análise com a investigação de como se configura sua relação com o eixo da "desordem", representado na peça pelo pequeno comércio, pelos capoeiristas e pelo meretrício, este último, apresentando características distintas dos demais, como será discutido adiante. Para compor este eixo, adotou-se neste ensaio uma postura relativamente empírica ao associar à "desordem" tudo aquilo que mantém em relação à "ordem" uma postura de oposição do tipo opressor-oprimido, ou ainda, a "desordem" seria o eixo que, em oposição ao eixo da "ordem", prefere a ruptura pela manutenção. Em termos gerais, se não é a mesma, esta definição compartilha muitos pontos da definição mobilizada por Cândido implicitamente em “Dialética da malandragem”.

A esfera denominada aqui como pequeno comércio consiste numa gama diversa e estereotipada de personagens (reverberando mais uma vez o realismo social de Dias Gomes), e compreende Galego, um imigrante dono de um pequeno estabelecimento, Dedé CospeRima, um trovador que vende seus versos, e Minha Tia, uma vendedora de acarajé, que também representa a dimensão do candomblé, contraponto essencial ao catolicismo e à "ordem" na peça.

Embora uma leitura equivocada tenda a aproximar Zé-do-Burro desse eixo - equivocada porque, apesar do estereótipo de miserável que normalmente acompanha os peregrinos, este era proprietário de terras antes de reparti-las com lavradores pobres por conta de sua promessa -, o protagonista de Dias Gomes está tão distante em dialogar moralmente com os representantes da "desordem", quanto com o eixo da "ordem", já analisado. O pagador de promessas nega reiteradamente as refeições oferecidas por Galego, dispensa os versos que poderiam ser feitos sobre ele por Dedé Cospe-Rima, capazes, supostamente, de angariar apoio dos leitores, e rejeita os acarajés oferecidos por Minha Tia (pelas mãos de Rosa). Da vendedora de acarajé e “ekédi” do Candomblé, Minha Tia, Zé-do-Burro ainda recusa algo decisivo para seu fim trágico: transmutar sua promessa de Santa Bárbara para Iansã, levando sua cruz até o terreiro de umbanda e cumprindo sua promessa - "Eu levo você lá! Você leva a cruz e a santa recebe! Você fica em paz com ela!” (Ibidem, p.78). Há aqui um dado importante a ser catalogado à figura do antimalandro. Como bem aponta DaMatta em relação aos peregrinos, embora acabe, por fim, subvertendo a ordem, a intenção é antes inaugurar 
uma nova relação de sentidos sociais, por seu isolamento, do que propriamente destituir a ordem vigente (1997, p.270), exatamente como faz Zé-do-Burro. Este, como renunciador, não ancora seus atos à subversão da ordem vigente, mas simplesmente no cumprimento de sua promessa, uma ordem íntima e de integridade considerada superior às demais proposições presentes no meio. Na peça, a capacidade de cumprir uma promessa, portanto, seria a pedra fundamental dessa nova ordem social possível de ser erigida sobre a ética particular do peregrino, mas nunca erigida pelo peregrino sobre si mesmo, nuance importantíssima para o entendimento da figura.

Seguindo a análise, uma segunda esfera a ser verificada no interior do eixo da "desordem" é representada pelos capoeiristas, que, apesar de figurarem bem tardiamente na peça (ao segundo quadro do segundo ato, mais precisamente), têm papel crucial, com o perdão do trocadilho, nos momentos decisivos e derradeiros do drama. Embora a relação entre eles seja bastante pontual, se resumindo, fisicamente, à cena em que Mestre Coca avisa Zé-do-Burro do cerco da polícia (GOMES, 2002, p.132 e ss.), aos lutadores protegendo o protagonista no momento do conflito e à colocação do corpo de peregrino já morto sobre a cruz; esta se torna decisiva para a caracterização da natureza do antimalandro, pois sua negativa em se retirar diante do aviso é, mais uma vez, ação condicionante de seu fim trágico. Além disso, no evento em que os capoeiristas se postam em torno do peregrino, a negação do antimalandro é tão característica que, mesmo na situação de intenso e íntimo contato físico com os lutadores, Zé-do-Burro permanece alheio a qualquer diálogo. Por mais que os capoeiristas se envolvam na briga para defendê-lo, não é a pedido de Zé-do-Burro que o fazem, este continua apartado de qualquer benefício advindo dos lutadores e só efetivamente se relacionará com eles, se é possível considerar como tal, quando os lutadores erguem seu corpo sobre a cruz e adentram a igreja, fazendo com que postumamente o devoto cumpra sua promessa.

Por fim, um último grupo que pode ser considerado componente do eixo da "desordem" é formado por Marli e Bonitão, representantes do meretrício. Cabe analisar de maneira própria esta esfera, pois Bonitão é o grande antagonista do drama e o maior responsável pela morte de Zé-do-Burro. Apesar do peregrino também não se envolver efetivamente com estas personagens, talvez seja apenas com elas que minimamente dialogue ao longo da peça. Primeiramente, ao aceitar que Bonitão leve Rosa para dormir num lugar adequado, com a observação importante de que nega o mesmo para si. Depois, quando Marli acusa Rosa de ter dormido com o cafetão, Zé-do-Burro aceita as acusações como indícios da suposta traição de sua mulher. Embora não seja muito, e não descaracterize o protagonista de sua natureza antimalandra, em virtude das ações especificamente não lhe dizerem respeito e não irem de 
encontro à sua promessa, no ambiente de total negação em que Zé-do-Burro se estabelece, tal confiança é digna de ser verificada e faz com que sejam aventadas possibilidades para explicar seu mecanismo.

Mesmo que não se pretenda aqui esgotar o argumento, a hipótese encontrada que melhor explica essa peculiaridade versa sobre a figura de Bonitão, que na peça se configuraria como um típico malandro, tal qual apontado por Cândido em seu artigo, e, dessa forma, dotado das habilidades necessárias para causar alterações no quadro estabelecido, no caso em questão, o isolamento e a intransigência de Zé-do-Burro. Já que no próximo item, para enfim listar as características do antimalandro, será analisado o artigo de Cândido, cabe aqui somente indicar as muitas características de Bonitão que são constitutivas da figura do malandro. São elas: explora a prostituta, mas não pede dinheiro emprestado; diz que não flerta com outras mulheres, senão com Marli - "É uma questão de princípios" (Ibidem, p.18) -, mas termina a peça com Rosa; apesar de sua condição marginal, foi ex-policial e tem boas relações com a polícia (Ibidem, p.29), o que proporciona até mesmo chamar o "Secreta" para averiguar a situação de Zé-do-Burro; mantém uma relação leviana com a culpa - "a gente pode apagar uma porção de noites. Isso não deixa marcas" (Ibidem, p.74) -; já se desfez, sem problemas, de uma promessa a Santo Antônio (Ibidem, p.21); e, por fim, Bonitão afirma, e que resume sua identificação com a figura do malandro, "toda coisa tem pelo menos duas maneiras de ser olhada. Uma de lá pra cá, outra de cá pra lá” (Ibidem, p.22). Como bem aponta DaMatta, por meio da análise da figura de Pedro Malasartes, o malandro é exatamente esse que faz uso das regras pertencentes ao sistema para atingir seus objetivos pessoais, sem alterá-las a princípio, mas que acaba por subjugar e inverter o panorama que se apresentava antes de suas ações tomarem corpo (1997, p.260 e ss.), ou seja, prática idêntica a de Bonitão sobre a realidade de Zé-do-Burro em $O$ pagador de promessas.

\section{Enfim, o antimalandro}

Até este ponto do ensaio, espera-se que tenha sido identificada uma lista significativa de ações realizadas por Zé-do-Burro que orbitem o tema da intransigência, previamente eleito para figurar como núcleo opositivo da atitude do malandro apontada por Cândido em "Dialética da malandragem". Não obstante já seja possível intuir como se caracterize a figura do antimalandro, torna-se necessário evidenciar o motivo da escolha da intransigência como este valor central de oposição e, ainda, pormenorizar os atributos de Zé-do-Burro que 
respondem especificamente por essa caracterização, tarefa a ser mediada, constantemente, pelo supra citado artigo de Cândido.

Para o crítico uspiano, um dos grandes méritos da obra Memória de um sargento de milícias, de Manuel Antônio de Almeida, consiste na retratação de um universo muito próprio ao do brasileiro do século XIX, em que se configura um diálogo constante entre os extratos da "ordem" e da "desordem”, com esta cercando a ordem "de todos os lados" (CÂNDIDO, 2000, p.31). O malandro, representado no livro principalmente por Leonardo Filho, seu protagonista, seria aquele capaz de transitar com desenvoltura entre esses dois eixos, lançando mão de características caras a cada um deles a depender da situação em que essas características sejam exigidas. A leitura de Schwarz sobre Cândido revela a conjunção de análises no plano estético e social que realiza este último para chegar a uma espécie de síntese histórica profunda da sociedade brasileira (SCHWARZ, 1997).

Com base no artigo de Cândido, e seu comentário schwarziano, é possível analisar simetricamente $O$ pagador de promessa, de Dias Gomes. Pode-se considerar que o dramaturgo igualmente retrata de maneira hábil um universo bastante comum ao vivenciado pelo brasileiro do início da década de 60 do século passado, com o país prestes a sofrer o golpe militar de 1964. Há nesta conjuntura, de maneira inversa àquela apontada por Cândido, um extrato da "desordem", cercado pelo extrato da "ordem" por todos os lados. Nesse contexto, o antimalandro, analogamente, seria aquele incapaz de transitar entre esses dois eixos, no caso da peça, amparado pela promessa que fizera à santa. Também na forma, a simetria se faz presente entre o romance de Manoel Antônio de Almeida e a peça de Dias Gomes, pois esta, diferentemente dos saltos narrativos daquela, mantêm seu foco todo o tempo numa única praça com o peregrino atrelado à sua promessa e à sua cruz. Eis, portanto, a razão para se identificar o antimalandro pelo signo da intransigência, enquanto se associa o malandro ao dialogismo, com a conseqüência de que algumas características apontadas por Cândido em seu artigo podem, inclusive, ser mobilizadas para o entendimento do protagonista de Dias Gomes e as relações que o peregrino (não) estabelece no decorrer do enredo.

Mais uma vez como um simples comentário, é possível destacar a notável simetria entre esses heróis também no que se refere ao êxito de cada um deles. Não é difícil afirmar que tanto Zé-do-Burro quanto Leonardo Filho tenham sucesso em sua empreitada, embora o século que os distancia - em todas as suas diferenças sócio-políticas - tenha transmutado a noção de valor do conceito de "vitória". Enquanto se configura como êxito para o arrivista carioca ascender malandramente ao eixo da ordem, para o antimalandro baiano, o triunfo significaria resistir com honra sem trair seus princípios morais. No contexto de Zé-do-Burro, 
a vitória é mais resistir do que vencer. Por esses motivos, embora tratados aqui muito rapidamente, optou-se por tratar o antimalandro como a figura especular do malandro definido por Cândido e elegeu-se a intransigência como seu mais caro valor.

Justificada a escolha do lugar central da intransigência para o antimalandro, resta traçar com mais detalhes como se apresenta essa figura tão bem delineada por Dias Gomes em sua peça, na personagem de Zé-do-Burro.

Uma primeira característica que pode ser relacionada indubitavelmente ao antimalandro é seu sentimento constante de culpa, na verdade, uma culpa projetada sobre a transgressão daquilo a que ele se apega, ou, ainda, em outros termos, uma possibilidade de remorso. No caso de Zé-do-Burro, essa culpabilidade exacerbada impede com que tome qualquer espécie de medida que se desvie ou supostamente transgrida a promessa feita - "nesse negócio de milagres, é preciso ser honesto" (GOMES, 2002, p.11). Usar almofadas para amenizar o peso da cruz, considerar o pátio como ambiente da igreja - e cumprir sua promessa à porta do templo -, levar a cruz ao terreiro de Iansã, e, até mesmo, aceitar o auxílio de alguém (ao que se pode acusar um certo exagero): nenhum ato é realizado pelo antimalandro que possa se opor a um código de conduta que ele se estabelecera anteriormente. Em contrapartida, Cândido afirma sobre a figura do malandro: "o remorso não existe, pois a avaliação das ações é feita segundo sua eficácia" (2000, p.41). Diante dessa afirmativa do crítico, restabelecendo como escopo o antimalandro, aprofundam-se as reflexões sobre a culpabilidade de Zé-doBurro. Para a personagem, pouco importa a eficácia de suas ações. Se fugisse nas inúmeras vezes a que foi incentivado a isso, se aceitasse o apoio do trovador ou do repórter, por exemplo, teria tomado ações racionalmente mais eficazes. Contudo, a avaliação das ações para o peregrino sempre é feita segundo sua promessa (por hipótese, outros antimalandros elegerão cernes próprios para julgarem suas ações) e, portanto, tudo o que se afasta da promessa gera remorso a Zé-do-Burro e confere-lhe a retidão de caráter que se identifica na personagem, mesmo que muitas vezes exagerada. Na tentativa de evitar esse remorso, o peregrino jamais fica impedido de agir de forma a deixar sua promessa em risco.

Outro valor que podemos identificar em Zé-do-Burro, em oposição à figura do malandro, é sua imobilidade. Não somente sua imobilidade física - evidente, já que o peregrino permanece toda a obra num único lugar, enquanto Leonardo Filho está sempre se movimentando no romance -, mas uma imobilidade social e, principalmente, uma imobilidade moral é a marca distintiva do antimalandro. É difícil traduzir exatamente qual seja este traço, mas está claro que, enquanto ao malandro estão associados valores como 
"móvel”, "fluido", "periférico", "aventureiro" 4 , em oposição, ao antimalandro se associariam as idéias de "imóvel", "sólido", "central" e "conservador". Na peça, isso está bastante demarcado quando se opõem as ações de Bonitão e Zé-do-Burro, uma vez que o primeiro está sempre se movendo para transformar em sucesso suas artimanhas, enquanto o segundo permanece absolutamente estático, à espera das ações que o meio lhe irá exercer. Pode-se dizer, por fim, que esse panorama concede um caráter mais ativo ao malandro, em oposição a um caráter mais reativo do antimalandro, onde talvez esteja explicado o quadro social referente à "oportunidade" em que se insere o primeiro, enquanto este último se identificaria mais a um panorama de "repressão" ou "resistência", cada qual coerente à época em que a obra se desenvolve.

O terceiro e último ponto relevante, que será aqui realçado para evidenciar a distinção opositiva entre o malandro e o antimalandro, diz respeito à composição de suas trajetórias. Cândido afirma sobre o primeiro: "a história de Leonardo Filho é a velha história do herói que passa por diversos riscos até alcançar a felicidade" (Ibidem, p.33), após oscilar entre a ordem estabelecida e condutas transgressoras. O que se pode afirmar sobre Zé-do-Burro em relação a seu fim? Exatamente o contrário, o fim do antimalandro parece apontar sempre para a morte ${ }^{5}$. Mais do que isso, tal qual Cândido identifica como natureza do malandro - "nasce malandro feito, como se se tratasse de uma qualidade essencial, não um atributo adquirido por força das circunstâncias" (2000, p.20) -, parece residir no antimalandro uma tendência essencial a ser alvo de violência ou sacrifício daqueles que o circundam. Não se inferiu essa peculiaridade com base no fim recorrente a outros antimalandros, nem mesmo em simetria à análise realizada pelo crítico paulista, mas com base nas afirmações sobre violência que constam em A violência e o sagrado, de René Girard. O autor afirma que o sacrifício seria uma medida social que visa erradicar a possibilidade de violência generalizada e que o sacrificável, quando humano, deve apresentar um "vínculo muito frágil ou nulo com a sociedade", para que sua morte não gere um processo incontrolável de vinganças (1990, p.44). Além da aproximação constante ao longo do drama com a figura de Jesus Cristo (arquétipo ocidental do antimalandro?), cada negativa de Zé-do-Burro confirma-o como objeto sacrificável e afasta-o de possíveis auxílios daqueles que o cercam. Como sua característica primordial é esta intransigência ao diálogo com quaisquer dos eixos, "ordem" ou "desordem", é possível

\footnotetext{
${ }^{4}$ Cândido, principalmente na aproximação à figura do "pícaro", identifica também esse caráter no malandro. Ibidem, p.18-22.

5 DAMATTA (1990) indica como exemplos de peregrino, que podemos aproximar dos antimalandros, personagens como Augusto Matraga, de Guimarães Rosa, e Antônio Conselheiro, em Os sertões, ambos destinados a um fim trágico, p.299.
} 
afirmar que a partir do momento em que se é possível firmar na personagem sua caracterização de antimalandro, sua trajetória está definitivamente delineada para a tragédia, já que afasta de si qualquer auxílio que o pudesse resguardar da violência da sociedade sobre si mesmo.

Expôs-se neste item, complementando os exemplos reunidos no item anterior, as principais características do antimalandro, personificado na figura de Zé-do-Burro: sua intransigência, sua culpa exacerbada, sua imobilidade social e sua destinação à tragédia. $\mathrm{Na}$ peça de Dias Gomes, a personagem jamais fará uso de um "jeitinho" ${ }^{6}$ que re-signifique sua promessa diante de uma nova dinâmica de poderes nem aceitará qualquer auxílio que advenha da dimensão da "ordem" ou da dimensão da "desordem", permanecendo obstinado e, a seu ver, íntegro em relação à sua promessa. Todas essas características definiriam sua trajetória e seu fim no drama, fazendo com que se possa identificá-lo, assim como o malandro de Cândido, como um tipo recorrente e relativamente fixo de personagem ficcional.

\section{Conclusão}

Algumas objeções importantes poderão ser feitas a este trabalho e convém expor antecipadamente os argumentos em que este artigo se embasou em relação a estas críticas possíveis. Certamente outras críticas incisivas poderão ser encetadas contra este ensaio, além das previsões do autor - quanto mais forem válidas estas linhas, mais se tornam passíveis de críticas relevantes não previstas -, quanto a estas, contudo, este ensaio fia sua incapacidade na certeza de que haverá melhores e mais bem acabados textos a respeito que darão continuidade à abordagem do tema.

A primeira crítica relevante antevista versa sobre a profundidade deste artigo, que é claramente superficial e breve demais para dar conta do assunto que aborda: a caracterização de um novo tipo literário nacional (ou transnacional) que reverbera, como razoavelmente prova DaMatta com a identificação próxima do Caxias, como um tipo social ou um modo de comportamento em nossa cultura. Quanto a este ponto, este ensaio contra-argumenta de duas formas. A primeira, a de que realmente o escopo deste ensaio é muito mais modesto do que se possa pensar, ou, ao menos, seu ponto de partida foi diametralmente outro. Não buscou encontrar este padrão ético ${ }^{7}$ na literatura e na sociedade, mas antes buscou entender a

\footnotetext{
${ }^{6}$ Segundo DAMATTA (1990), p.291, o "jeitinho” pode ser definido como uma astúcia para utilizar as regras em benefício próprio, "sem destruí-las ou colocá-las em causa".

${ }^{7}$ Aqui em seu sentido original, referente ao conceito aristotélico de ethos, ARISTÓTELES (1992), p.35.
} 
personagem Zé-do-Burro e sua trajetória de renúncia. A partir, então, de algumas observações sobre a personagem, tornou-se possível estender padrões e hipóteses para além do limite de $O$ pagador de promessas. A segunda forma de se justificar ante a essa crítica é de que, em virtude da complexidade do tema, não seria possível para qualquer outro autor ou obra abarcar tudo o que tenha de relevante a ser dito a respeito. Todos os trabalhos relacionados a um tema tão multifacetado, na verdade, realizam o mesmo, apontam para uma direção que auxilia na delimitação de conceitos e temas. De maneira semelhante, embora incomparavelmente menor do que Cândido, DaMatta e Girard, este ensaio tenta encontrar hipóteses que dêem conta das relações estabelecidas por uma personagem no interior de um drama e que definiriam ou influenciariam em sua morte, auxiliando, assim, na formulação de uma idéia geral sobre alguns dos conceitos mais complexos que permeiam a questão.

Uma segunda crítica relevante diz respeito a algumas personagens que não foram analisadas devidamente. Mais do que o "esquecimento" da Beata, que é absolutamente periférica e mais representa um tipo social aludido do que propriamente uma personagem, há neste ensaio a omissão da análise do papel da Imprensa na peça. Eximir-se de uma análise tão importante é claramente um atestado de inaptidão para fazê-lo, e realmente a natureza dúbia desta instância na peça assomaria um grau de complexidade inesperado a este ensaio. Como se analisar a contento um núcleo que ora se comporta como representante da "ordem" - o Repórter é ex-militar, almeja a eleição política do peregrino e possui relações com o Governador -, ora como representante da "desordem" - ao se intitular representante do povo, ao traduzir como "reforma agrária" a divisão das terras de Zé-do-Burro e ao ter clientes que financiam suas campanhas? Seria possível propor que a Imprensa constitua uma instância pautada no dialogismo do malandro, ao medir seus sucessos pela eficácia e transitar com habilidade entre os eixos da "ordem" e da "desordem"? Embora seja uma questão interessantíssima, infelizmente, por sua complexidade, não pôde ocupar um lugar neste ensaio, que assume tal apagamento e ressente-se do mesmo.

Outras omissões mais pontuais ainda podem ser apontadas neste trabalho: a falta de uma análise sobre a forma da peça, em vez da prioridade ao conteúdo; não haver observado algumas peculiaridades clássicas - a ação restrita a um dia, o coro formado pela capoeira que Dias Gomes mantém em sua peça; a ausência de considerações sobre a recepção da obra, tanto na década de 60, quando foi encenada pela primeira vez, quanto em sua versão cinematográfica, e sua permanência como representativa de nossa cultura; e, por fim, a inexistência aqui uma análise de maior fôlego sobre o papel do Candomblé e sua relação com a "ordem", representada pela Igreja Católica. A todos essas objeções, este ensaio se defende 
na afirmação de que, infelizmente, é imperativo um recorte muito estrito para se realizar um artigo de vulto tão modesto. Certamente a peça analisada não obteve ainda o número de estudos e ensaios a que está destinada e estes textos vindouros se voltarão para essas questões, eximindo in absentia este artigo de suas falhas.

Enfim, este ensaio se encerra em uma análise minuciosa de seu início, seu título, que previamente já anunciava todo o desenvolvimento argumentativo que iria apresentar ao longo destas páginas.

Zé-do-Burro, o personagem central da obra-prima de Dias Gomes, tão nuclear ao drama que, mesmo quando não é o foco da cena, é remetido e referenciado nos diálogos das personagens coadjuvantes. Personagem também central a este ensaio, que buscou analisar suas características intrínsecas e as relações que estabelece com as demais personagens do drama. Sempre balizado, convém lembrar, pela análise que Cândido realiza quanto à figura do malandro.

Destino aqui entendido bem próximo ao sentido clássico do termo hybris, mas não totalmente coincidente a ele, como um fim reservado ao herói desde o início de sua trajetória. Como bem aponta DaMatta, "é muito comum observar a formação do renunciador [grifo do autor] como uma obra do destino, [...], que lhe abre as portas da marginalidade, mudando sua orientação deste para um outro mundo" (1997, p.270). Destino aqui, do mártir, entendido como algo latente e preconizado na caracterização da figura do antimalandro. Em outras palavras, como se a constituição da figura do antimalandro já antevisse sua predisposição e predestinação ao martírio.

Trágico porque a peça de Dias Gomes nos mostra exatamente a trajetória de um herói, homem de índole elevada, superior a nós (ARISTÓTELES, 1992, p.21-23), que antes do drama propriamente encenado, já havia peregrinado quarenta quilômetros e dois com uma pesada cruz de madeira às costas e que, ao fim da peça, encontrará a morte explicada por sua natureza heróica de enfrentamento.

O antimalandro: esta figura da recusa, que não se permite o diálogo de concessões éticas adotado pelo malandro e que, por isso, tem sua trajetória vital entre as esferas da "ordem" e da "desordem" prejudicada por esta intransigência. O argumento central deste ensaio é a proposição de que a figura do antimalandro, a princípio, na análise da peça de Dias Gomes, mas podendo ser aplicada a demais obras da literatura ocidental, é um aparato teórico relevante para a análise literária, especialmente em Literatura Brasileira. Por meio de sua conceituação, obtêm-se conquistas significativas no entendimento do mártir, do processo de caracterização de personagens, da relação estabelecida entre elas e, eventualmente, da 
representação dramática das tensões sociais que eram verificáveis à época prefigurada na obra. Assim como o malandro, parece que esta figura acaba por dizer tanto de si quanto do meio que a cerca.

\section{Referências}

ALMEIDA, Manuel Antônio de. Memórias de um sargento de milícias. São Paulo: Moderna, 1993.

ARISTÓTELES. Poética; tradução: Eudoro de Souza. São Paulo: Ars Poética, 1992. Retórica. São Paulo: Imprensa Nacional Casa da Moeda, 1998.

CÂNDIDO, Antônio. "Dialética da malandragem" in CÂNDIDO, Antônio. O Discurso e a Cidade. São Paulo / Rio de Janeiro: Duas Cidades / Ouro Azul, 2000, p. 17-46.

CUNHA, Antônio Geraldo da. Dicionário Etimológico Nova Fronteira da Língua Portuguesa. Rio de Janeiro: Nova Fronteira, 1982.

GIRARD, René. A violência e o sagrado; tradução de Martha Conceição Gambini. São Paulo: Editora Universidade Estadual Paulista, 1990.

GOMES, Dias Alfredo. O pagador de promessas. Rio de Janeiro: Ediouro, 2002.

HOLLANDA, Sérgio Buarque de. Raízes do Brasil. São Paulo: Companhia das Letras, 1995.

MAMET, David. Três usos da faca: sobre a natureza e a finalidade do drama; tradução de Paulo Reis. Rio de Janeiro: Civilização Brasileira, 2001.

MATTA, Roberto da. Carnavais, malandros e heróis: para uma sociologia do malandro brasileiro. Rio de Janeiro: Rocco, 1997.

RIDENTI, Marcelo. Em busca do povo brasileiro. Rio de Janeiro: Record, 2000.

SCHWARZ, Roberto. Pressupostos, salvo engano, da "Dialética da Malandragem” in Que horas são? São Paulo: Companhia das Letras, 1997.

SZONDI, Peter. Teoria do drama moderno [1880-1950]; tradução: Luiz Sérgio Rêpa. São Paulo: Cosac \& Naify Edições, 2001. 